Article

\title{
Dye-sensitized photoanode decorated with pyridine additives for efficient solar water oxidation
}

\author{
Jiayuan Li a,t, Yong Zhu a, $\dagger$, Fei Li a,*, Guoquan Liu a, Suxian Xu a, Licheng Sun a,b,c \\ a State Key Laboratory of Fine Chemicals, DUT-KTH Joint Education and Research Center on Molecular Devices, Dalian University of Technology (DUT), \\ Dalian 116024, Liaoning, China \\ b Department of Chemistry, School of Engineering Sciences in Chemistry, Biotechnology and Health, KTH Royal Institute of Technology, Stockholm 10044, \\ Sweden \\ c Center of Artificial Photosynthesis for Solar Fuels, School of Science, Westlake University, Hangzhou 310024, Zhejiang, China
}

\section{A R T I C L E I N F O}

\section{Article history:}

Received 23 April 2020

Accepted 1 June 2020

Available online 5 April 2021

\section{Keywords:}

Dye-sensitized

photoelectrochemical cell

Water splitting

Photoanode

Surface modification

Pyridine derivatives

\begin{abstract}
A B S T R A C T
Splitting water into hydrogen and oxygen by dye-sensitized photoelectrochemical cell (DSPEC) is a promising approach to solar fuels production. In this study, a series of pyridine derivatives as surface additives were modified on a molecular chromophore and water oxidation catalyst co-loaded $\mathrm{TiO}_{2}$ photoanode, $\mathrm{TiO}_{2} \mid \mathrm{RuP}, 1\left(\mathrm{RuP}=\mathrm{Ru}\left(4,4^{\prime}-\left(\mathrm{PO}_{3} \mathrm{H}_{2}\right)_{2}-2,2^{\prime}\right.\right.$-bipyridine $)\left(2,2^{\prime} \text {-bipyridine }\right)_{2}, 1=$ $\mathrm{Ru}(\mathrm{bda})(\mathrm{L})_{2}$, (bda = 2,2'-bipyridine-6,6'-dicarboxylate, $\mathrm{L}=10$-(pyridin-4-yloxy)decyl)phosphonic acid). The addition of pyridine additives was found to result in up to $42 \%$ increase in photocurrent. Under simulated sun-light irradiation, $\mathrm{TiO}_{2} \mid \mathrm{RuP}, 1, \mathrm{P}_{1}\left(\mathrm{P}_{1}=4\right.$-Hydroxypyridine $)$ produced a photocurrent density of $1 \mathrm{~mA} / \mathrm{cm}^{2}$ at a bias of $0.4 \mathrm{~V} v s$. NHE in acetate buffer. Moreover, the observed photocurrents are correlated with the electron-donating ability of the substituent groups on pyridine ring. Transient absorption measurements and electrochemical impedance spectroscopy revealed that surface-bound pyridine can effectively retard the back-electron transfer from the $\mathrm{TiO}_{2}$ conduction band to the oxidized dye, which is a major process responsible for energy loss in DSPECs.
\end{abstract}

(C) 2021, Dalian Institute of Chemical Physics, Chinese Academy of Sciences. Published by Elsevier B.V. All rights reserved.

\section{Introduction}

In view of depleting fossil fuels and the concomitant drastic pollution of the environment, considerable concern is directed towards finding more sustainable and recyclable ways for energy storage and consumption [1-3]. Among the available resources, solar energy is considered the most promising one [4-8]. In order to convert solar energy into chemical fuels, hydrogen production by visible light-driven water splitting with dye-sensitized photoelectrochemical cell (DSPEC) is an efficient approach [9]. The working principle of the DSPEC photoanodes involves four steps: (1) excitation of chromophore by visible light; (2) excited-state electron injection into the conduction band of a wide band gap semiconductor; (3) water oxidation initiated by cross-surface or intra-assembly electron transfer from water oxidation catalysts (WOCs) to the oxidized chromophore; (4) transportation of injected electron to cathode with or without the assistance of a bias to drive $\mathrm{H}_{2}$ production

\footnotetext{
* Corresponding author. Tel: +86-411-84986247; Fax: +86-411-84986245; E-mail: lifei@dlut.edu.cn

${ }^{\dagger}$ These authors contributed equally to this work.

This work was supported by the National Natural Science Foundation of China (21872016), Liaoning Revitalization Talents Program (XLYC1807125), and the Swedish Energy Agency.

DOI: 10.1016/S1872-2067(20)63683-X | http://www.sciencedirect.com/journal/chinese-journal-of-catalysis | Chin. J. Catal., Vol. 42, No. 8, August 2021
} 
[10]. However, DSPEC has a major charge recombination process of back electron transfer of the injected electrons from the conduction band of $\mathrm{TiO}_{2}$ to oxidized photosensitizers, which causes considerable energy loss.

Various methods have been developed to prevent back electron transfer at the surface of DSPEC photoanode. These include the modification of water oxidation catalysts with anchoring groups bearing long alkyl chain [11,12], addition of surface-bound electron mediator [13] and using core-shell conductive substrates [14-17]. In particular, core-shell structured substrate such as $\mathrm{SnO}_{2} / \mathrm{TiO}_{2}$ was found to efficiently control the local interfacial dynamics and result in enhanced PEC activity. With this structure, electron injection from the excited chromophore to $\mathrm{TiO}_{2}$ shell is followed by rapid electron transfer through the thin shell to the core. The junction between two metal oxides effectively limits back electron transfer [15]. However, in this method, the overlayer metal oxide with nanometer thickness was fabricated by atomic layer deposition (ALD), which is relatively complicated and costly for manipulation.

In this study, we report an alternative and facile strategy for assembling dye-sensitized photoanode with reduced back electron transfer by surface binding of pyridine derivatives. The photoanode was fabricated by co-adsorption of a ruthenium (II) tris(2,2'-bipyridine) based chromophore and a $\mathrm{Ru}$-bda based molecular water oxidation catalyst (bda = 2,2'-bipyridine-6,6'-dicarboxylate) on the surface of mesoporous $\mathrm{TiO}_{2}$ film (Scheme 1). Without the use of a core-shell substrate, modification of electrode surface by pyridine additives resulted in notably improved PEC performance with photocurrent density increased by up to $42 \%$ under 1 simulated sun at $0.4 \mathrm{~V}$ vs. NHE. The observed PEC performance of pyridine-modified photoanodes can be correlated to the electron-donating ability of the substituent groups on pyridine ring.

\section{Experimental}

\subsection{Materials}

All chemical agents were commercially available and used without further purification. Solvent were distilled and dried

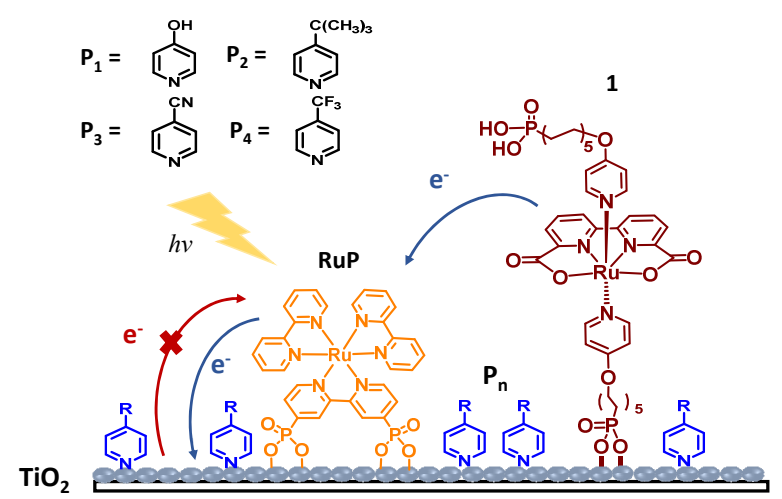

Scheme 1. Schematic illustration of $\mathrm{TiO}_{2}$ photoanode decorated with a dye photosensitizer (RuP), molecular catalyst (1) and pyridine derivatives. according to the standard methods. Fluorine doped tin oxide (FTO) coated glass were purchased from Dalian HeptaChroma SolarTech Co., Ltd. (thickness of $\sim 2.2 \mathrm{~mm}$, transmittance of $>$ $90 \%$, resistance $<15 \Omega / \mathrm{cm}^{2}$ ). The FTO slide was washed in aqueous detergent solution, acetone, ethanol for 30 minutes and then dried for future use. Synthesis of complexes RuP and 1 $\left(\mathrm{RuP}=\mathrm{Ru}\left(4,4^{\prime}-\left(\mathrm{PO}_{3} \mathrm{H}_{2}\right)_{2}-2,2^{\prime}\right.\right.$-bipyridine $)\left(2,2^{\prime} \text {-bipyridine }\right)_{2}, 1=$ $\mathrm{Ru}(\mathrm{bda})(\mathrm{L})_{2}, \quad\left(\right.$ bda $=2,2^{\prime}$-bipyridine-6,6'-dicarboxylate, $\mathrm{L}=$ 3-(pyridine-4-yloxy)decyl-phosphonic acid)) were prepared according to previously published methods and performed under $\mathrm{N}_{2}$ atmosphere $[11,18]$.

\subsection{Characterization}

${ }^{1} \mathrm{H}$ NMR Spectra were collected at $25{ }^{\circ} \mathrm{C}$ using a Bruker AVANCE III 500 instrument. Electrospray ionization mass spectra were recorded on a Q-Tof Micromass spectrometer (Manchester, England). UV-Vis absorption measurements were carried out on an Agilent 8453 spectrophotometer. Electrochemical measurements were taken with a CHI760E electrochemical station (Shanghai Chenhua, China).

\subsection{Preparation of electrodes}

$\mathrm{TiO}_{2}$ and was prepared according to a modified method in literature [11]. Typically, a $6 \mu \mathrm{m}$ thickness $\mathrm{TiO}_{2}$ film was coated in FTO electrode by doctor blade and dried for $30 \mathrm{~min}$ at 120 ${ }^{\circ} \mathrm{C}$. The resulted film was heated to $450{ }^{\circ} \mathrm{C}$ at a rate of 2.5 ${ }^{\circ} \mathrm{C} / \mathrm{min}$ and kept at this temperature for $1 \mathrm{~h}$. After cooling to room temperature, the resulting film was heated with $0.02 \mathrm{M}$ $\mathrm{TiCl}_{4}$ solution at $70{ }^{\circ} \mathrm{C}$ for $1 \mathrm{~h}$ before calcination at $450{ }^{\circ} \mathrm{C}$ for 1 h. Subsequently, it was cut by glass cutter and the active area was made to be $1 \mathrm{~cm}^{2}$. The morphology of $\mathrm{TiO}_{2}$ film was clarified by scanning electron microscopy (SEM, Fig. S1). In Fig. S1, the electrodes consisted of $6 \mu \mathrm{m}$ layers of $\mathrm{TiO}_{2}$ on FTO substrates. $\mathrm{TiO}_{2}$ film is composed of nanoparticles with an average size of approximately 20-50 nm. These nanoparticles were loosely packed into a porous structure, which is favorable for exposing more specific surface area for RuP sensitization. The FTO conducting glasses sintered by nanostructure $\mathrm{TiO}_{2}$ were immersed in a $10 \mathrm{~mL}$ methanol solution that contained $0.1 \mathrm{mM}$ RuP for $2 \mathrm{~h}$. In a subsequent step, it were soaked in another methanol solution containing $1(0.1 \mathrm{mM})$ for $2 \mathrm{~h}$, followed by soaking in a methanol solution containing the pyridine derivatives $(1 \mathrm{mM})$ for $20 \mathrm{~min}$. It were then washed with methanol for several times and dried in dark at room temperature to obtain $\mathrm{TiO}_{2} \mid \mathrm{RuP}, 1, \mathrm{P}_{1-4}$. The nano ITO (Sn(IV)-doped tin oxide) films were prepared according to previously published methods [11].

\subsection{Photoelectrochemical methods}

All photoelectrochemical measurements were carried out at room temperature by using a standard three-electrode system (CHI 760E electrochemical station). The working electrode was a photoanodes, $\mathrm{Ag} / \mathrm{AgCl}$ (0.194 V vs. NHE) and Pt wire were used as the reference and counter electrodes, respectively. The 
electrolyte was a $0.1 \mathrm{M}$ acetate buffer ( $\mathrm{pH} 4.6$ ) containing $0.1 \mathrm{M}$ $\mathrm{NaClO}_{4}$. The simulated solar illumination was obtained by passing light from a 300W Xenon arc lamp (CEACLIGHT) equipped with a filter (400 nm cutoff filter for PEC measurements or AM 1.5 filter for ABPE measurement), the power intensity of the incident light was calibrated to $100 \mathrm{~mW} / \mathrm{cm}^{2}$ using a THORLABS S401C power meter. The incident-photon conversion efficiency (IPCE) at each wavelength was determined by using illumination from a $300 \mathrm{~W}$ Xenon arc lamp (CEAULIGHT). The monochromatic light was produced using a CEAULIGHT CEL-IS151 monochromator with a $10-\mathrm{nm}$ bandpass. The IPCE value was calculated using the Eq. (1):

$\operatorname{IPCE}(\%)=\left[1240 \times\left(U_{\text {light }}-J_{\text {dark }}\right)\right] /(\lambda \times P \lambda) \times 100 \%$

The applied bias photo-to-current efficiency (ABPE) was calculated from current-potential curves under AM 1.5G 1 sun illumination using the Eq. (2):

$\operatorname{ABPE}(\%)=\left[\left(U_{\text {light }}-J_{\text {dark }}\right) \times\left(1.23-V_{\mathrm{RHE}}\right)\right] / P_{\text {light }}$

Where $V_{\mathrm{RHE}}$ is the applied potential versus RHE, Jlight and $J_{\text {dark }}$ are the measured photocurrent and dark current, respectively.

\subsection{Determination of faradaic efficiency}

The amounts of oxygen and hydrogen evolution were determined by gas chromatography. Before the measurement, the sealed electrolytic cell was degassed with Argon for 15 min to remove residual air. The amount of oxygen and hydrogen evolution after $1 \mathrm{~h}$ of electrolysis at $0.4 \mathrm{~V}$ vs. NHE was measured. The Faradaic efficiency was calculated according to the integrated charge $(\mathrm{Q})$ passed and the amount of $\mathrm{O}_{2}$ evolved using the Eq. (3):

$$
\eta(\%)=\left(96485 \times n_{02} \times 4\right) / Q
$$

\subsection{Transient absorption measurements}

The transient absorption kinetics were measured under open circuit conditions with the photoanode standing in an acetate buffer $(\mathrm{pH}=4.6)$. The measurements were recorded by a LP920 laser flash spectrometer (Edinburgh Instrument) in combination with a probe xenon light (Edinburgh Instrument, Xe920). Transient absorption spectroscopy was measured at $450 \mathrm{~nm}$ with the laser pulse excited at $532 \mathrm{~nm}, 5-7 \mathrm{~ns}, 5$ $\mathrm{mJ} /$ pulse, operated at $1 \mathrm{~Hz}$.

\section{Results and discussion}

A DSPEC device was shown in Scheme 2. The photoanode was fabricated by co-loading a ruthenium polypyridine chromophore (phosphonate-derivatized ruthenium (II) tris(2,2'bipyridine) (RuP) and a water oxidation catalyst $\mathrm{Ru}(\mathrm{bda})(\mathrm{L})_{2}$, (L = 3-(pyridine-4-yloxy)decyl-phosphonic acid) (1) on the surface of $\mathrm{TiO}_{2}$-sintered fluorine-doped tin oxide (FTO) slide based on a known procedure [11]. Catalysts bearing long alkyl chain linkers have been reported to prevent the recombination of excited electrons with oxidized catalysts due to the isolation of the catalytic center from the electrode surface. The resulting long-lived intermediates enable the accumulation of multiple oxidative equivalents required by water oxidation.

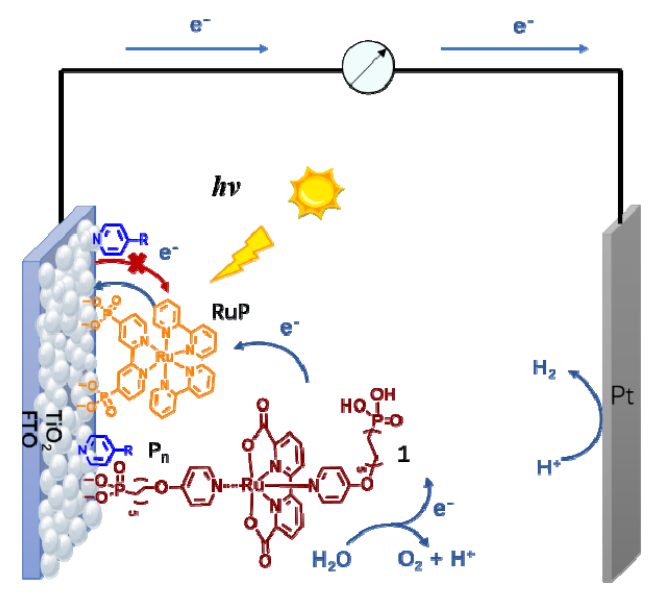

Scheme 2. Schematic illustration of the DSPEC composed of a $\mathrm{TiO}_{2}$ photoanode modified with a dye photosensitizer (RuP), a molecular catalyst (1) and pyridine derivatives, and a Pt cathode.

The surface coverage of $\mathrm{RuP}$ on $\mathrm{TiO}_{2}$ was estimated relying on a solution method. First, the sensitized RuP was fully desorbed from electrode in $0.1 \mathrm{M} \mathrm{NaOH}$ solution (water:ethanol = $1: 1, v / v)$. The dissolved chromophore was quantified by UV-Vis spectroscopy based on the characteristic MLCT absorption band at $450 \mathrm{~nm}$ (Fig. S2).

For $\mathrm{TiO}_{2} \mid \mathrm{RuP}, 1$, the loading of chromophore and catalyst was determined to be $4 \times 10^{-8}$ and $8 \times 10^{-9} \mathrm{~mol} / \mathrm{cm}^{2}$, respectively, corresponding to a ratio of $5: 1$. The presence of excess chromophore has been suggested to benefit the accumulation of holes at catalytic sites due to fast hole hopping among surface-bound RuP molecules [19].

The electrochemical properties of $\mathrm{TiO}_{2} \mid \mathrm{RuP}, 1$ was investigated by cyclic voltammograms (CVs) in acetate buffer solution $(\mathrm{pH}=4.6)$. In Fig. 1 , the $\mathrm{CV}$ of $\mathrm{TiO}_{2} \mid \mathrm{RuP}, 1$ shows a redox couple of $\mathrm{Ru}^{\mathrm{II}} / \mathrm{III}$ of 1 at $0.63 \mathrm{~V}$ versus the normal hydrogen electrode (NHE), which is followed by a prominent catalytic current initiated at $1.1 \mathrm{~V}$. The irreversible anodic peak observed at $1.38 \mathrm{~V}$ was attributed to $\mathrm{Ru}^{\mathrm{II}}$ III $^{\mathrm{II}}$ of RuP, a revisable peak at the same potential was observed for $\mathrm{TiO}_{2} \mid \mathrm{RuP}$ under the same conditions. The electrochemical behavior of $\mathrm{TiO}_{2} \mid \mathrm{RuP}, 1$ indicates that photo-induced water oxidation is thermodynamically favorable on this film.

Pyridine derivatives $\mathrm{P}_{1}, \mathrm{P}_{2}, \mathrm{P}_{3}$, and $\mathrm{P}_{4} \quad \mathrm{P}_{1}=$ 4-hydroxypyridine, $\mathrm{P}_{2}=$ 4-tert-butylpyridine, $\mathrm{P}_{3}=$ 4-cyanopyridine, $\mathrm{P}_{4}=4$-(trifluoromethyl)pyridine, Scheme 1) were decorated on $\mathrm{TiO}_{2}$ electrodes by soaking the electrode in a methanol solution containing $1 \mathrm{mM}$ of the desired additive for $20 \mathrm{~min}$. The resulting film was washed by methanol for several times to eliminate the unbound additives. The long pair of electrons on the nitrogen atom of pyridine ring was previously suggested to coordinate to the unoccupied $3 d$ orbitals of $\mathrm{Ti}^{3+}$ on the $\mathrm{TiO}_{2}$ surface $[20,21]$, thus resulting in a distinct binding mode from that of conventional phosphonic and carboxylic acid anchors. Based on this analysis, a high stability for pyridine binding was expected in aqueous solutions within a wide range of $\mathrm{pH}$ values. By measuring the amounts of detached pyridine in a methanol solution, a roughly similar coverage on $\mathrm{TiO}_{2}$ was 


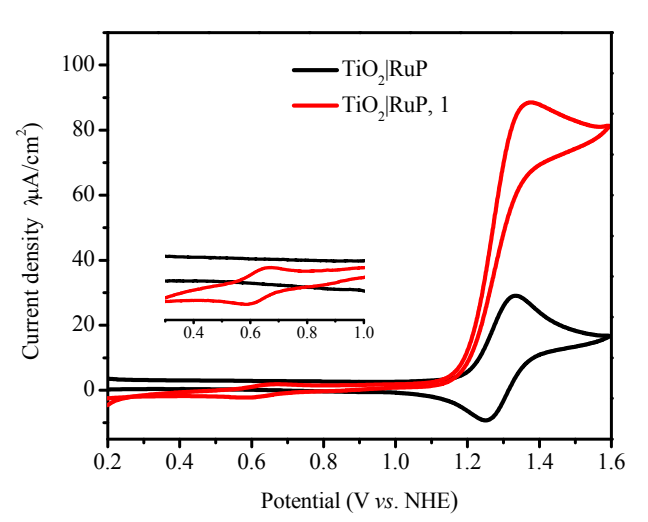

Fig. 1. Cyclic voltammograms (CVs) of $\mathrm{TiO}_{2} \mid \mathrm{RuP}$ and $\mathrm{TiO}_{2} \mid \mathrm{RuP}, 1$ at a scan rate of $10 \mathrm{mV} / \mathrm{s}$ in acetate buffer $(\mathrm{pH} 4.6$ with $0.1 \mathrm{M}$ acetic acid/acetate and $0.5 \mathrm{M} \mathrm{NaClO4}$ ). The inset shows the magnified CV curves between 0.4 to $1.0 \mathrm{~V}$.

estimated for $\mathrm{P}_{1-4}\left(8.61 \times 10^{-8} \mathrm{~mol} / \mathrm{cm}^{2}\right.$ for $\mathrm{P}_{1}, 7.24 \times 10^{-8}$ $\mathrm{mol} / \mathrm{cm}^{2}$ for $\mathrm{P}_{2}, 1.22 \times 10^{-7} \mathrm{~mol} / \mathrm{cm}^{2}$ for $\mathrm{P}_{3}$, and $1.29 \times 10^{-7}$ $\mathrm{mol} / \mathrm{cm}^{2}$ for $\mathrm{P}_{4}$, Fig. S3).

To eliminate the influence of chromophore and to gain a better $\mathrm{CV}$ response, catalyst 1 and pyridine additives were co-loaded on high surface conductive nano ITO films to explore their electrochemical behaviors. The CVs of nano ITO|1, nano ITO|1, $\mathrm{P}_{1}$, nano ITO|1, $\mathrm{P}_{2}$, nano ITO|1, $\mathrm{P}_{3}$ and nano ITO|1, $\mathrm{P}_{4}$ were tested in acetate buffer solution at $\mathrm{pH}=4.6$. For all samples, the reversible redox peaks at $E^{1 / 2}=0.63 \mathrm{~V}$ and $E^{1 / 2}=0.95$ $\mathrm{V}$ (vs. NHE) were assigned to $\mathrm{Ru}^{\mathrm{II}}{ }^{\mathrm{III}}$ and $\mathrm{Ru}^{\mathrm{III}}-\mathrm{OH}_{2} / \mathrm{Ru}^{\mathrm{IV}}-\mathrm{OH}$ of 1 , respectively (Fig. S4). While the irreversible peak initiated at $1.1 \mathrm{~V}$ due to catalytic water oxidation was not altered by additive adsorption, suggesting that the added pyridine has no influence on the catalytic properties of co-loaded 1.

The PEC performance of the $\mathrm{TiO}_{2} \mid \mathrm{RuP}, 1$ and $\mathrm{TiO}_{2} \mid \mathrm{RuP}, 1$, $\mathrm{P}_{1-4}$ was investigated in aqueous acetate buffer $(\mathrm{pH}=4.6)$ with a three-electrode setup with $\mathrm{TiO}_{2} \mid \mathrm{RuP}, 1, \mathrm{P}_{1-4}$ as the working electrode, $\mathrm{Ag} / \mathrm{AgCl}$ as the reference electrode and $\mathrm{Pt}$ wire as the counter electrode. Shown in Fig. 2(a) is the chopped-light photocurrents measured at a constant applied bias of $0.4 \mathrm{~V} v s$. NHE under 1 sun, $400 \mathrm{~nm}$ cut-off illumination. The electrodes deco-

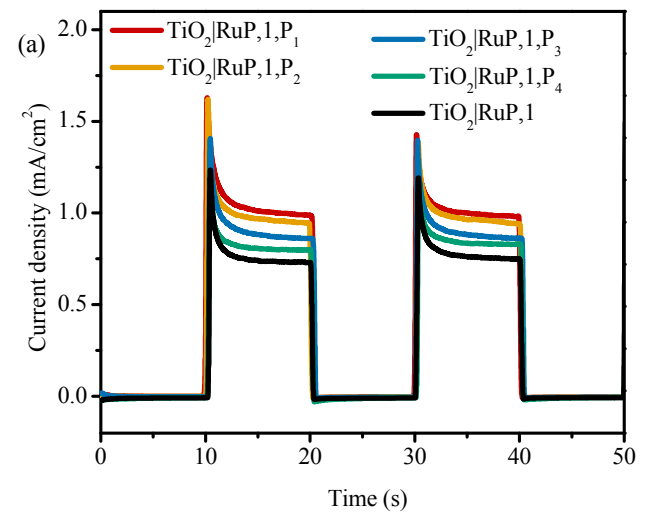

rated with $\mathrm{P}_{1-4}$ show photocurrent densities from 0.8 to 1.1 $\mathrm{mA} / \mathrm{cm}^{2}$, all of them are superior to that of $\mathrm{TiO}_{2} \mid \mathrm{RuP}, 1$ with a photocurrent of $0.70 \mathrm{~mA} / \mathrm{cm}^{2}$ at the same potential. In addition, variation of the substituents on the para-position of pyridine ring imposed a notable effect on the PEC performance of dye-sensitized photoanodes, the PEC activity decreases in the order of $\mathrm{P}_{1}>\mathrm{P}_{2}>\mathrm{P}_{3}>\mathrm{P}_{4}$ in terms of the magnitude of photocurrent density. The trend shown here is consistent with the order of electron-donating capability of the substituents as - $\mathrm{O}^{-}$ $>-\mathrm{C}\left(\mathrm{CH}_{3}\right)_{3}>-\mathrm{CN}>-\mathrm{CF}_{3}$. Note that 4-hydroxypyridine $\left(\mathrm{P}_{1}\right)$ with a $\mathrm{p} K_{\mathrm{a}}$ of 3.2 is deprotonated in acetate buffer, the strong conjugation effect makes it the most electron-donating additive.

Being the most active photoanode of this series, the long-term durability of the $\mathrm{TiO}_{2} \mid \mathrm{RuP}, 1, \mathrm{P}_{1}$ electrode was evaluated by chronopotentiometric measurement, Fig. 2(b). The photocurrent density at $0.4 \mathrm{~V}$ was found to decrease from 1 to $0.75 \mathrm{~mA} / \mathrm{cm}^{2}$ within $400 \mathrm{~s}$ under sustained light illumination, corresponding to a decay of $25 \%$ in photocurrent. This is a normal limitation for RuP sensitized photoanodes due to the desorption of RuP from the surface of $\mathrm{TiO}_{2}$ via hydrolysis. The durability of photoanode could be improved by ALD coating another layer of $\mathrm{TiO}_{2}$ or $\mathrm{Al}_{3} \mathrm{O}_{2}$ on the surface of DSPEC photoanode $[16,22]$. Another promising approach is the insertion of an electron relay between dye and catalyst, which gives rise to rapid recovery of dye from its oxidative state and reduces the opportunity of dye decomposition [23]. However, this issue is not the primary focus of this study. After $1 \mathrm{~h}$ photolysis, the evolved oxygen was quantified by gas chromatography and a Faradaic efficiency of $80 \%$ was evaluated.

It should be noted that $\mathrm{TiO}_{2} \mid \mathrm{RuP}, 1, \mathrm{P}_{1}$ showed comparable activity with respect to its structural analogous, $\mathrm{TiO}_{2} / \mathrm{SnO}_{2} \mid \mathrm{RuP}, 1$, based on a core-shell substrate $\left(0.8 \mathrm{~mA} / \mathrm{cm}^{2}\right.$ at $0.4 \mathrm{~V} v s$. NHE in acetate buffer) in terms of photocurrent [11]. The core-shell structure is known to inhibit back electron transfer by forming a heterojunction between two semiconductors [14]. In this regard, the surface-bound pyridine derivatives play a similar role in inhibiting charge recombination as the core-shell structure did. Compared with the core-shell film fabricated by ALD technique, the mesoporous $\mathrm{TiO}_{2}$ film brings considerable convenience to electrode fabrication.

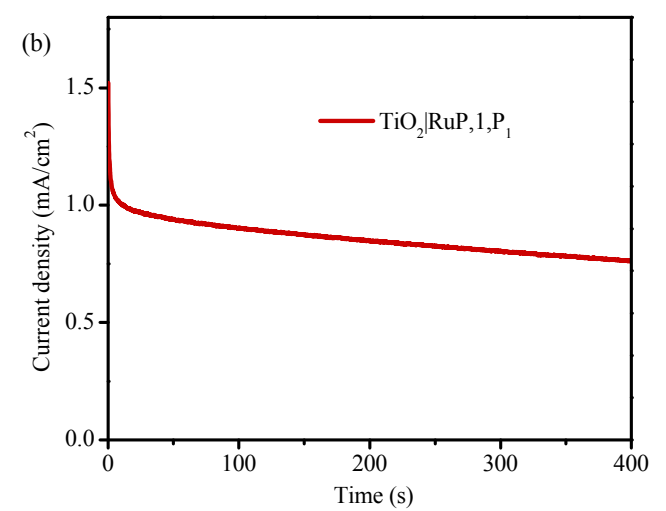

Fig. 2. (a) Photocurrent-time (I-T) traces of $\mathrm{TiO}_{2}\left|\mathrm{RuP}, 1, \mathrm{P}_{1}, \mathrm{TiO}_{2}\right| \mathrm{RuP}, 1, \mathrm{P}_{2}, \mathrm{TiO}_{2}\left|\mathrm{RuP}, 1, \mathrm{P}_{3}, \mathrm{TiO}_{2}\right| \mathrm{RuP}, 1, \mathrm{P}_{4}$, and TiO $2 \mid \mathrm{RuP}, 1$ photoanodes under chopped light irradiation at a constant bias of $0.4 \mathrm{vs}$. NHE; (b) Long-term illumination of the TiO $\mathrm{R}_{2} \mid \mathrm{RuP}_{1}, 1, \mathrm{P}_{1}$. All experiments were performed in acetate buffer ( $\mathrm{pH} 4.6$ with $0.1 \mathrm{M}$ acetic acid/acetate and $0.5 \mathrm{M} \mathrm{NaClO}_{4}$ ) with a white light source adjusted to $100 \mathrm{~mW} / \mathrm{cm}^{2}$ and a $400 \mathrm{~nm}$ cutoff filter. 
The incident photon-to-current efficiency (IPCE) of $\mathrm{TiO}_{2} \mid \mathrm{RuP}, 1, \mathrm{P}_{1}$ was measured as a function of wavelength. As presented in Fig. 3(a), the IPCE spectrum is well matched with the UV-Vis absorption spectrum of $\mathrm{TiO}_{2} \mid \mathrm{RuP}, 1$ in Fig. S5, with the maximum IPCE value of $13.6 \%$ appearing at $470 \mathrm{~nm}$. Based on the IPCE data and the potential-dependent photocurrents, the optimal applied bias photo-to-current efficiency (ABPE) for $\mathrm{TiO}_{2} \mid \mathrm{RuP}, 1, \mathrm{P}_{1}$ was calculated to be $0.85 \%$ at $0.3 \mathrm{~V}$ under 1 sun, AM 1.5G irradiation, Fig. 3(b).

Pyridine compounds such as tert-Butyl pyridine $(t-\mathrm{BP})$ is an important additive for dye-sensitized solar cells (DSCs), it has been widely accepted that $t$-BP tends to adsorb onto the $\mathrm{TiO}_{2}$ surface and block dye molecules from charge carrier recombination with the redox couples in solution [24]. This is clearly not the case for DSPECs, as no external redox couple is needed for water splitting. In DSPECs, the energy loss has been considered to be dominated by back electron transfer of photoinjected electrons from the conduction band of $\mathrm{TiO}_{2}$ to surface-bound oxidized dyes [25,26].

In order to characterize the electron transfer kinetics at interface, transient absorption spectroscopy (TA) of dye and pyridine sensitized $\mathrm{TiO}_{2}$ films was carried out under open circuit conditions [19]. For all samples, we observed rapid photoinduced charge injection on a timescale $(<10 \mathrm{~ns})$ unable to be solved by the apparatus, followed by charge recombination on a time scale of microseconds (Fig. 4). These processes can be described as RuP excitation followed by electron injection to give a powerful oxidant, $\mathrm{Ru}^{I I I} \mathrm{P}$ (Eqs. (4) and (5)). The transient bleaching recovery recorded at $450 \mathrm{~nm}$ corresponding to back electron transfer from $\mathrm{TiO}_{2}$ conduction band to $\mathrm{Ru}$ IIIP (Eqs. (4)-(6)) can be well fitted by a tri-exponential function (Eq. (7)) [27]. The lifetime of $\mathrm{Ru}^{\mathrm{III} P}$ in $\mathrm{TiO}_{2}\left|\mathrm{RuP}, \mathrm{P}_{1}, \mathrm{TiO}_{2}\right| \mathrm{RuP}, \mathrm{P}_{2}$, $\mathrm{TiO}_{2}\left|\mathrm{RuP}, \mathrm{P}_{3}, \mathrm{TiO}_{2}\right| \mathrm{RuP}, \mathrm{P}_{4}$, and $\mathrm{TiO}_{2} \mid \mathrm{RuP}$ were evaluated to be 87, 55, 52, 49 and $37 \mu$ s, respectively (Fig. 4, Table S1). The longer lifetime for the sample with a more electron-donating pyridine additive is consistent with the tendency of photocurrent in Fig. 2(a).

$$
\begin{gathered}
\mathrm{TiO}_{2}\left|\mathrm{Ru}^{\mathrm{II}} \mathrm{P} \stackrel{h v}{\rightarrow} \mathrm{TiO}_{2}\right| \mathrm{Ru}^{\mathrm{II}} * \mathrm{P} \\
\mathrm{TiO}_{2}\left|\mathrm{Ru}^{\mathrm{II}} * \mathrm{P} \rightarrow \mathrm{TiO}_{2}\left(\mathrm{e}^{\mathrm{e}}\right)\right| \mathrm{Ru}{ }^{\mathrm{III}} \mathrm{P} \\
\mathrm{TiO}_{2}(\mathrm{e})\left|\mathrm{Ru}^{\mathrm{III}} \mathrm{P} \rightarrow \mathrm{TiO}_{2}\right| \mathrm{Ru}{ }^{\text {II }} \mathrm{P} \\
k_{\text {obs }}=\mathrm{A}_{1} \mathrm{e}^{-k 1 t}+\mathrm{A}_{2} \mathrm{e}^{-k 2 t}+\mathrm{A}_{3} \mathrm{e}^{-k 3 t}
\end{gathered}
$$

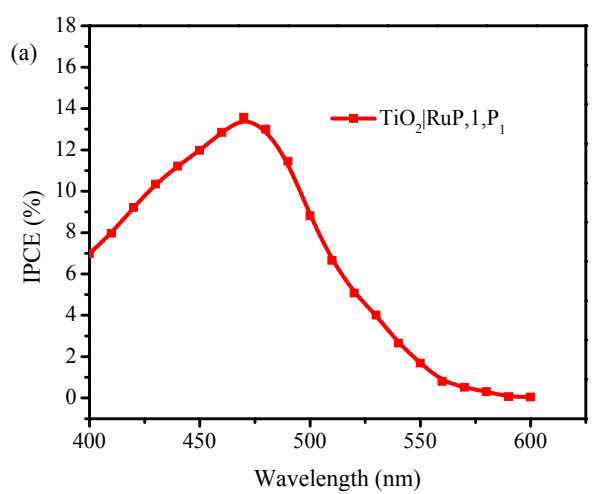

The charge recombination kinetics of dye-sensitized nanocrystalline $\mathrm{TiO}_{2}$ films has been intensively studied by Durrant and other researchers [28-30]. It was suggested that a high density of sub-bandgap or trap states lying below the conduction band edge of $\mathrm{TiO}_{2}$ are active in mediating electron-transfer processes in these films. The occupancy of these states plays an important role in the charge recombination. Under open circuit conditions and high excitation power $\left(5 \mathrm{~mJ} / \mathrm{cm}^{2}\right)$, the occupancy is determined by the laser excitation and the charge recombination will therefore be dominated by electrons injected by the laser excitation [29,31]. Since the efficiency of photoinduced electron injection was not expected to be largely altered by adding surface additives, the observed extended lifetime of $\mathrm{Ru}^{\text {IIIP }}$ was contributed to an effect of added pyridine in retardation of back electron transfer.

Back to the real PEC circumstance, catalytic water oxidation occurs with an external potential and the light intensity is much lower than used for flash photolysis $\left(<1 \mathrm{~mJ} / \mathrm{cm}^{2}\right)$. Followed excitation and electron injection, the oxidized chromophore may recombine not only with electrons injected into the $\mathrm{TiO}_{2}$, but also with electrons occupying $\mathrm{TiO}_{2}$ conduction band/trap states due to the application of an external bias. According to the previous reports, the modification of pyridine derivatives on $\mathrm{TiO}_{2}$ would lead to a negative shift in the conduction band $[29,30,32]$. At a given potential, this upward shift will result in a lower electron occupancy and reduce the rate of charge recombination. Based on this understanding, the sequence of the surface additive-modulated photocurrents in Fig. 2(a) can be well explained.

The interfacial charge transfer of $\mathrm{TiO}_{2}\left|\mathrm{RuP}, \mathrm{P}_{1}, \mathrm{TiO}_{2}\right| \mathrm{RuP}, \mathrm{P}_{2}$, $\mathrm{TiO}_{2}\left|\mathrm{RuP}, \mathrm{P}_{3}, \mathrm{TiO}_{2}\right| \mathrm{RuP}, \mathrm{P}_{4}$ and $\mathrm{TiO}_{2} \mid \mathrm{RuP}$ were also studied in the dark based on electrochemical impedance spectroscopy (EIS). The larger radius of Nyquist plot in Fig. 5 represents a higher resistance toward interfacial electron transfer. The impedances shown by these films in the order of $\mathrm{TiO}_{2} \mid \mathrm{RuP}, \mathrm{P}_{1}$ $(568 \mathrm{~K} \Omega)>\mathrm{TiO}_{2}\left|\mathrm{RuP}, \mathrm{P}_{2}(539 \mathrm{~K} \Omega)>\mathrm{TiO}_{2}\right| \mathrm{RuP}, \mathrm{P}_{3}(438 \mathrm{~K} \Omega)>$ $\mathrm{TiO}_{2}\left|\mathrm{RuP}, \mathrm{P}_{4}(400 \mathrm{~K} \Omega)>\mathrm{TiO}_{2}\right| \mathrm{RuP}(168 \mathrm{~K} \Omega)$ agree well with the role of pyridine in inhibiting back electron transfer. In our case, pyridine molecules were absorbed on the surface of $\mathrm{TiO}_{2}$ and therefore the electrons in close proximity to the $\mathrm{TiO}_{2}$ surface would have been electrostatically repelled from the sur-

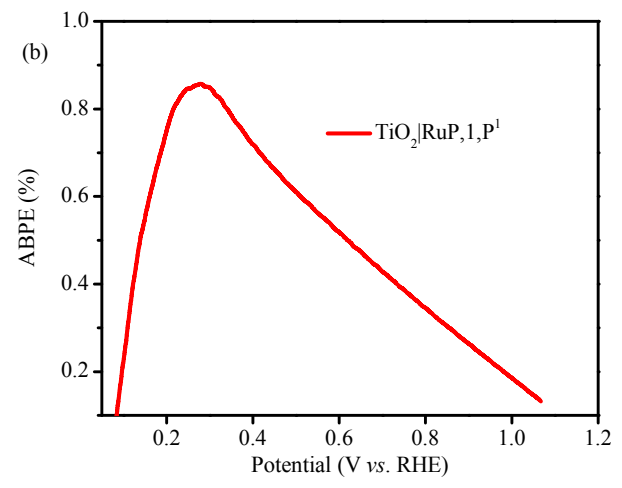

Fig. 3. (a) Incident photon-to-current efficiencies (IPCE) of $\mathrm{TiO}_{2} \mid \mathrm{RuP}, 1, \mathrm{P}_{1}$ electrode at $0.4 \mathrm{~V}$ vs. NHE; (b) Applied bias photo-to-current efficiency (ABPE) of $\mathrm{TiO}_{2} \mid \mathrm{RuP}, 1, \mathrm{P}_{1}$ electrode for photoelectrochemical water splitting at $100 \mathrm{~mW} / \mathrm{cm}^{2}$ light illumination with AM 1.5 filter. All experiments were performed in acetate buffer ( $\mathrm{pH} 4.6$ with $0.1 \mathrm{M}$ acetic acid/acetate and $\left.0.5 \mathrm{M} \mathrm{NaClO}_{4}\right)$. 

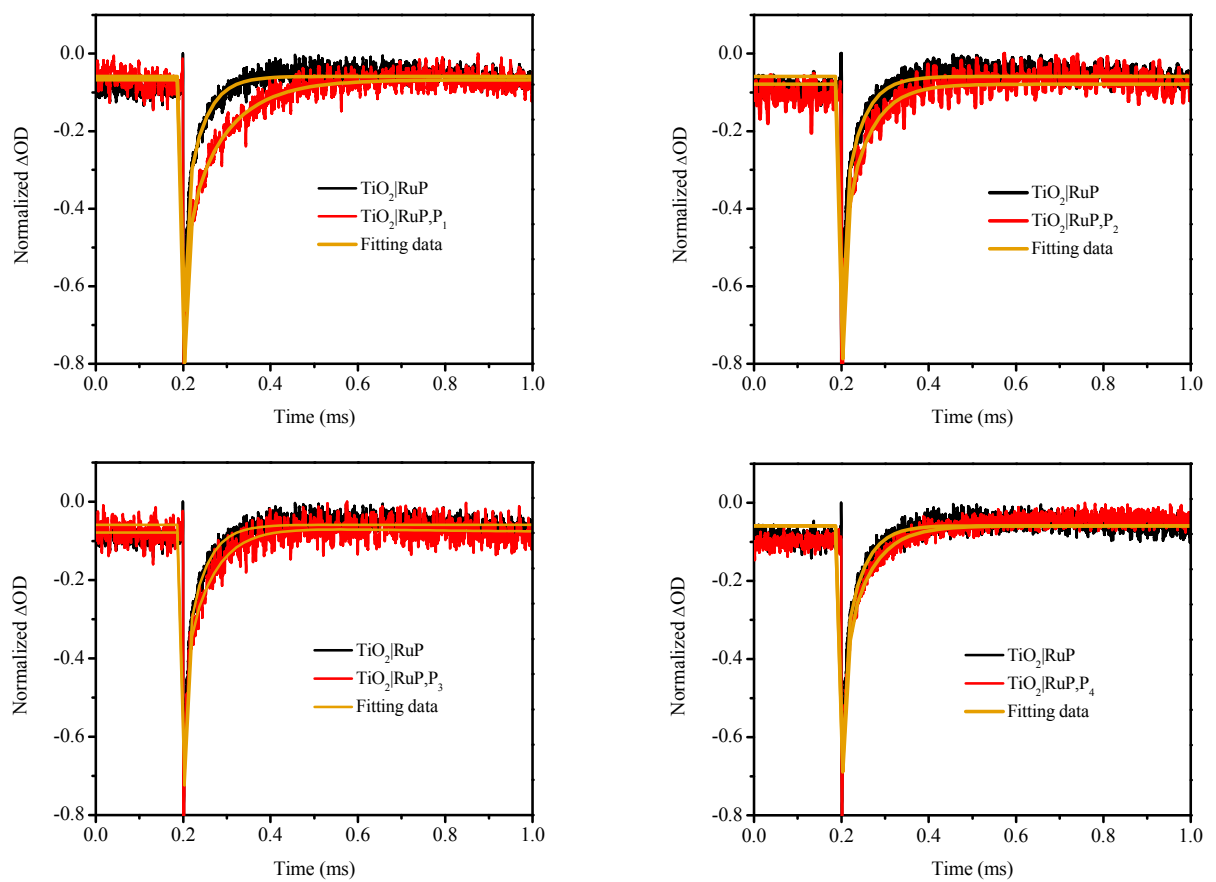

Fig. 4. Normalized transient bleaching recovery curves of $\mathrm{TiO}_{2} \mid \mathrm{RuP}$ and $\mathrm{TiO}_{2} \mid \mathrm{RuP}, \mathrm{P}_{1-4}$, monitored at $450 \mathrm{~nm}$ following $532 \mathrm{~nm}$ laser excitation in acetate buffer ( $\mathrm{pH} 4.6$ with $0.1 \mathrm{M}$ acetic acid/acetate and $0.5 \mathrm{M} \mathrm{NaClO}_{4}$ ).

face, leading to small electronic coupling between electrons and dye molecules [33].

\section{Conclusions}

In summary, we have developed a novel strategy for dye-sensitized photoanode by immobilization of small molecules of pyridine derivatives on $\mathrm{TiO}_{2}$ film. The surface modification of pyridine molecules could efficiently inhibit back electron transfer at the hybrid interface and improve the PEC performance. The finding that $\mathrm{TiO}_{2} \mid \mathrm{RuP}, 1, \mathrm{P}_{1}$, with added 4-hydroxypyridine, exhibits comparable activity to the photoanode based on the ALD core-shell $\mathrm{TiO}_{2}$ structure, together

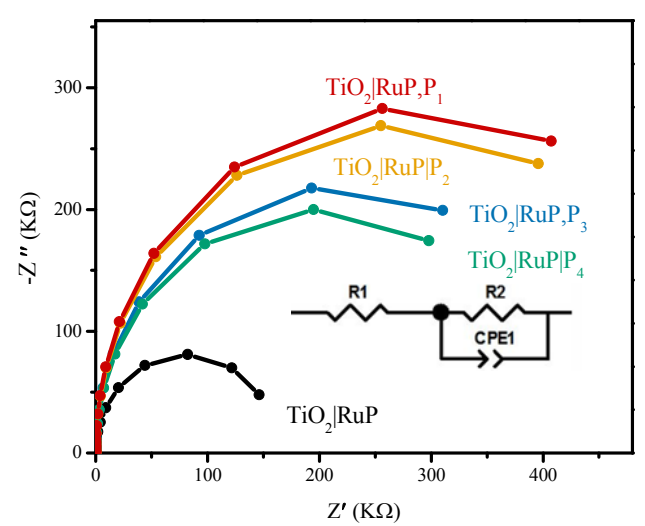

Fig. 5. Nyquist plot of $\mathrm{TiO}_{2} \mid \mathrm{RuP}, \mathrm{P}_{1-4}$ and $\mathrm{TiO}_{2} \mid \mathrm{RuP}$ electrodes used a three-electrode system acetate buffer ( $\mathrm{pH} 4.6$ with $0.1 \mathrm{M}$ acetic acid/acetate and $0.5 \mathrm{M} \mathrm{NaClO}_{4}$ ) in the dark. (Inset) Equivalent circuit used to fit Nyquist of electrodes. with the finding of a direct correlation between the electron-donating ability of pyridine derivatives and photocurrents open a new avenue for designing highly efficient DSPECs.

\section{Electronic supporting information}

Supporting information is available in the online version of this article.

\section{References}

[1] J. W. Huang, P. F. Yue, L. Wang, H. D. She, Q. Z. Wang, Chin. J. Catal,, 2019, 40, 1408-1420.

[2] X. Li, J. G. Yu, M. Jaroniec, X. B. Chen, Chem. Rev., 2019, 119, 3962-4179.

[3] R. C. Shen, J. Xie, Y. N. Ding, S. Y. Liu, A. Adamski, X. B. Chen, X. Li, ACS Sustain. Chem. Eng., 2019, 7, 3243-3250.

[4] F. Li, C. Y. Xu, X. H. Wang, Y. Wang, J. Du, L. C. Sun, Chin. J. Catal., 2018, 39, 446-452.

[5] T. R. Cook, D. K. Dogutan, S. Y. Reece, Y. Surendranath, T. S. Teets, D. G. Nocera, Chem. Rev., 2010, 110, 6474-6502.

[6] L. C. Wang, S. Cao, K. Guo, Z. J. Wu, Z. Ma, L. Y. Piao, Chin. J. Catal., 2019, 40, 470-475.

[7] R. C. Shen, J. Xie, Q. J. Xiang, X. B. Chen, J. Z. Jiang, X. Li, Chin. J. Catal., 2019, 40, 240-288.

[8] J. Shen, R. Wang, Q. Q. Liu, X. F. Yang, H. Tang, J. Yang, Chin. J. Catal., 2019, 40, 380-389.

[9] F. J. Niu, D. G. Wang, F. Li, Y. M. Liu, S. H. Shen, T. J. Meyer, Adv. Energy Mater., 2020, 10, 1900399.

[10] D. L. Ashford, M. K. Gish, A. K. Vannucci, M. K. Brennaman, J. L. Templeton, J. M. Papanikolas, T. J. Meyer, Chem. Rev., 2015, 115, 13006-13049.

[11] D. G. Wang, S. L. Marquard, L. Troian-Gautier, M. V. Sheridan, B. D. Sherman, Y. Wang, M. S. Eberhart, B. H. Farnum, C. J. Dares, T. J. 


\title{
Graphical Abstract
}

Chin. J. Catal., 2021, 42: 1352-1359 doi: 10.1016/S1872-2067(20)63683-X

Dye-sensitized photoanode decorated with pyridine additives for efficient solar water oxidation

Jiayuan Li, Yong Zhu, Fei Li *, Guoquan Liu, Suxian Xu, Licheng Sun Dalian University of Technology, China;

KTH Royal institute of Technology, Sweden;

Westlake University, China

Surface modification of pyridine on dye-sensitized $\mathrm{TiO}_{2}$ photoanode leads to improved photocurrent due to a role of pyridine molecule on retarding charge recombination at the electrode surface.

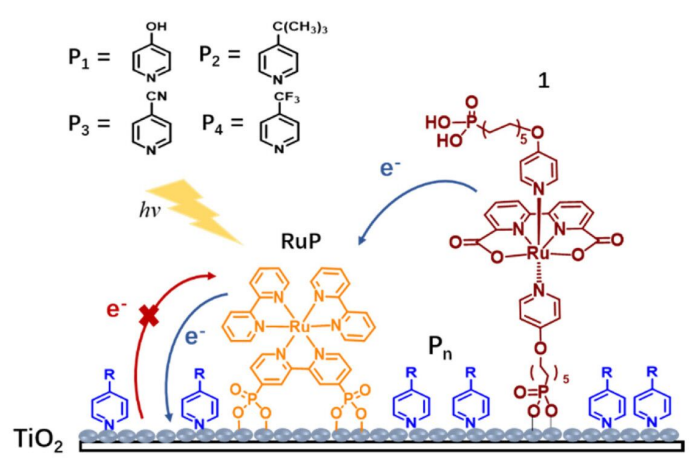

[23] D. G. Wang, F. J. Niu, M. J. Mortelliti, M. V. Sheridan, B. D. Sherman, Y. Zhu, J. R. McBride, J. L. Dempsey, S. H. Shen, C. J. Dares, F. Li, T. J. Meyer, Proc. Natl. Acad. Sci. USA, 2019, 117, 13259-13260.

[24] L. Yang, R. Lindblad, E. Gabrielsson, G. Boschloo, H. Rensmo, L. C. Sun, A. Hagfeldt, T. Edvinsson, E. Johansson, ACS Appl. Mater. Interfaces, 2018, 10, 11572-11579.

[25] W. J. Youngblood, S. A. Lee, Y. Kobayashi, E. A. Hernandez-Pagan, P. G. Hoertz, T. A. Moore, A. L. Moore, D. Gust, T. E. Mallouk, J. Am. Chem. Soc., 2009, 131, 926-927.

[26] Y. X. Zhao, J. R. Swierk, J. D. Megiatto Jr, B. Sherman, W. J. Youngblood, D. Qin, D. M. Lentz, A. L. Moore, T. A. Moore, D. Gust, T. E. Mallouk, Proc. Natl. Acad. Sci. USA, 2012, 109, 15612-15616.

[27] M. K. Brennaman, A. O. T. Patrocinio, W. J. Song, J. W. Jurss, J. J. Concepcion, P. G. Hoertz, M. C. Traub, N. Y. Murakami Iha, T. J. Meyer, Chemsuschem., 2011, 4, 216-227.

[28] R. R. Knauf, M. K. Brennaman, M. R. Norris, J. L. Dempsey, J. Phys. Chem. C, 2013, 117, 25259-25268.

[29] S. A. Haque, Y. Tachibana, R. L. Willis, J. E. Moser, M. Grätzel, D. R. Klug, J. R. Durrant, J. Phys. Chem. B, 2000, 104, 538-547.

[30] S. A. Haque, E. Palomares, B. M. Cho, A. N. M. Green, N. Hirata, D. R. Klug, J. R. Durrant, J. Am. Chem. Soc., 2005, 127, 3456-3462.

[31] J. T. Kirner, R. G. Finke, ACS Appl. Mater. Interfaces, 2017, 9, 27625-27637.

[32] J. Y. Kim, J. Y. Kim, D. K. Lee, B. S. Kim, H. Kim, M. J. Ko, J. Phys. Chem. C, 2012, 116, 22759-22766.

[33] R. Katoh, M. Kasuya, S. Kodate, A. Furube, N. Fuke, N. Koide, J. Phys. Chem. C, 2009, 113, 20738-20744.

\section{修饰吡啶衍生物的染料敏化光阳极水氧化性能的研究}

\author{
李佳原 ${ }^{\mathrm{a}, \dagger}$, 朱 勇 ${ }^{\mathrm{a}, \dagger}$, 李 斐 $\mathrm{a}^{*}$, 刘国权 ${ }^{\mathrm{a}}$, 许素显 ${ }^{\mathrm{a}}$, 孙立成, $\mathrm{a}, \mathrm{c}$ \\ ${ }^{a}$ 大连理工大学精细化工国家重点实验室, 大连理工大学-瑞典皇家工学院分子器件联合中心, 辽宁大连116024, 中国

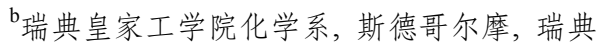 \\ c西湖大学理学院, 人工光合作用与太阳能燃料中心, 浙江杭州 310024 , 中国
}

摘要: 染料敏化光电化学电池(DSPECs)是构建人工光合作用体系的潜在方式, 其优势在于可通过优化染料结构来拓展可 见光吸收范围, 从根本上提高太阳能利用效率. 染料敏化光阳极在受激发产生电荷分离之后, 激发电子注入 $\mathrm{TiO}_{2}$ 半导体导 带, 由于其导带位置比传统的可见光半导体, 如 $\mathrm{BiVO}_{4}$ 和 $\mathrm{Fe}_{3} \mathrm{O}_{4}$ 等相比较负, 因此理论上可以在较小的偏压下取得较大的光 电转换效率, 也更有利于和光阴极相耦合实现无偏压分解水. 电荷传输动力学研究表明, 注入到 $\mathrm{TiO}_{2}$ 导带的电子向氧化态 
光敏剂和催化剂的回传是造成体系能量损失的主要原因, 集中体现在光电流密度和效率的降低. 目前, 已经报道了多种手 段来减少DSPECs光阳极表面的电子回传, 包括使用带有长烷基链的针定基团对水氧化催化剂进行修饰, 在半导体表面引 入电子中介体以及使用核-壳结构的基底等. 其中, $\mathrm{SnO}_{2} / \mathrm{TiO}_{2}$ 基底被广泛应用在染料敏化光阳极中, 这种基底可以提高光 生电子的注入效率, 同时两种金属氧化物之间的异质结有效抑制了电子回传, 从而提高了DSPECs的光电活性. 然而, 核-壳 结构基底需要使用原子层沉积技术来制备, 所以操作相对复杂. 本文基于 Ru-bda(bda $=2,2^{\prime}-$ 联吡啶-6,6'-二羧酸)结构的分 子水氧化催化剂和带有磷酸修饰基团的三联吡啶钉通过共吸附的方式制备染料敏化光阳极, 在不使用核-壳结构基底的情 况下, 利用吡啶衍生物对 $\mathrm{TiO}_{2}$ 电极表面的修饰来减少电子回传.

本文利用一系列吡啶衍生物作修饰负载在 $\mathrm{TiO}_{2}$ 光阳极上 $\left(\mathrm{TiO}_{2} \mid \mathrm{RuP}, 1 ; \mathrm{RuP}=\mathrm{Ru}\left(4,4^{\prime}-\left(\mathrm{PO}_{3} \mathrm{H}_{2}\right)_{2}-2,2^{\prime}-\right.\right.$-联吡啶 $)\left(2,2^{\prime}-\right.$-联吡 啶 $)_{2} ; 1=\mathrm{Ru}(\mathrm{bda})(\mathrm{L})_{2}, \mathrm{bda}=2,2^{\prime}$-联吡定- $6,6^{\prime}$-二羧酸, $\mathrm{L}=\left(10\right.$-吡啶-4-基氧基)癸基)膦酸. 在 $100 \mathrm{~mW} / \mathrm{cm}^{2}$ 的白光照射下 $(\lambda>$ $400 \mathrm{~nm}$ ), $\mathrm{TiO}_{2} \mid \mathrm{RuP}, 1, \mathrm{P}_{1}$ ( $\mathrm{P}_{1}=4$-羟基吡啶)光阳极在 $0.4 \mathrm{~V}$ (vs. NHE)的外加偏压下获得了 $1 \mathrm{~mA} / \mathrm{cm}^{2}$ 的光电流密度, 其光电流 比未修饰吡定的光阳极增加了 $42 \%$. 同时, 其入射光子-电流转化效率在 $470 \mathrm{~nm}$ 波长的单色光光照下达到最大, 为 $13.6 \%$. 经过吡啶衍生物所修饰的光阳极光电性能和文献中利用核-壳结构基底所制备的类似光阳极性能相当, 且光电流密度随吡 啶对位取代基供电性能的增强而增大. 瞬态吸收光谱和电化学阻抗谱测试表明, 吡啶吸附在光阳极上能有效地抑制界面 上的电子回传, 延长电荷分离寿命, 是光电流增加的根本原因, 这也表明有机小分子修饰是提高染料敏化光阳极性能的简 单、有效的策略.

关键词: 染料敏化光电化学电池; 水分解; 光阳极; 表面修饰; 吡啶衍生物

收稿日期: 2020-04-23. 接受日期: 2020-06-01. 上网时间: 2021-04-05.

*通讯联系人. 电话: (0411)84986247; 传真: (0411)84986245; 电子信箱: lifei@dlut.edu.cn

†共同第一作者

基金来源：国家自然科学基金(21872016); 辽宁省兴辽英才计划(XLYC1807125); 瑞典能源部.

本文的电子版全文由Elsevier出版社在ScienceDirect上出版(http://www.sciencedirect.com/journal/chinese-journal-of-catalysis). 